УДК 635.655:631.526.3, DOI 10.31210/visnyk2018.02.10

(C) 2018

\author{
Білявська Л. Г., кандидат сільськогосподарських наук, \\ Васецький Ю. П., аспірант \\ (науковий керівник - кандидат сільськогосподарських наук Л. Г. Білявська) \\ Білявський Ю. В., кандидат біологічних наук, \\ Діянова А. О., фахівець II категорії \\ Полтавська державна аграрна академія
}

\title{
СКОРОСТИГЛИЙ СОРТ СОЇ АВАНТЮРИН
}

\section{Рецензент - доктор сільськогосподарських наук, професор В. М. Писаренко}

Головною метою досліджень було створення скоростиглих $і$ високоврожайних сортів сої для всіх зон Украӥни з високою технологічністю, тривалістю періоду вететаиії 80-95 днів, урожайністю насіння 3,04,0 m/2а, вмістом протеӥну 40-43\%, вмістом жиру 22-26\%. Для створення сортів $i$ впровадження $\ddot{x}$ y Полтавській, Харківській, Сумській, Дніпропетровській областях використано джерела адаптивності до лімітуючих факторів (иляхом гібридизачіі) з метою оцінки на посухостійкість, стійкість проти хвороб, до кислих трунтів і комплексу кліматичних чинників. Базуючись на довготривалому практичному досвіді в селекиії сої, методом гібридизаиії джерел адаптивності до стресових чинників довкілля виведено скоростиглий сорт з підвищеним базовим потенціалом - Авантюрин. Сорт занесено до Державного реєстру сортів рослин, придатних для поширення в Україні. Представлено окремі вимоги до елементів агротехніки даного сорту.

Ключові слова: соя, сорт, селекиія, скоростиглість, характеристика сорту, господарчі ознаки, врожайність.

Постановка проблеми. В Україні стрімко зростають посівні площі під соєю. Країна зайняла перше місце в Свропі з площ та валового виробництва зерна сої.

Сучасний ринок сортів сої $є$ надзвичайно динамічним і привабливим, особливо в умовах зростання попиту. Жорсткі умови виробництва, на тлі змін клімату, стимулюють виробничників до активного пошуку сортів, здатних формувати високий рівень врожайності високоякісного насіння. Впровадження нових сучасних сортів сої дозволяе значно підвищити врожайність за умов дотримання головних вимог щодо їх вирощування $[1,2]$.

Сьогодні значна кількість виробників сої активно цікавиться скоростиглими сортами, і їх частка постійно збільшується. Проте переважна більшість сортів сої має територіально обмежену зону вирощування та не має стійкості до посухи. Тому низка сучасних сортів із відмінними характеристиками та високим генетичним потенціалом займає лише окремі регіони вирощування.
Універсальних скоростиглих сортів сої, пристосованих до комплексу стресових чинників, досить мало. Реалізація генетичного потенціалу сорту залежить також від технології вирощування в конкретних грунтово-кліматичних і ресурсно-організаційних умовах.

У сучасних умовах сорт залишається не тільки засобом збільшення урожайності, але і стає фактором, без якого неможливо реалізувати накопичений генетичний потенціал, задовольнити вимоги споживача та переробника [4]. Проте і досі виробникам сої важко підібрати сорт, який відповідає комплексу вимог і спроможний щорічно давати стабільно високі врожаї.

Аналіз основних досліджень i публікацій, у яких започатковано розв'язання проблеми. У різних грунтово-кліматичних умовах країни у сучасних сортів можливі зміни тривалості вегетаційного періоду, продуктивності, хімічного складу насіння, стійкості проти шкідливих організмів та впливу стресів через відсутність знань сортових особливостей [5]. Створені скоростиглі високоврожайні сорти з високим генетичним потенціалом та відповідним рівнем стійкості проти біотичних і абіотичних факторів середовища займають свій регіон вирощування. Проте на ефективність їх використання продовжують впливати погодні умови, різноманітні стресові чинники та жорстка конкуренція іноземних сортів. Базуючись на довготривалому практичному досвіді в селекції сої, у Полтавському селекцентрі виведено скоростиглі сорти 3 підвищеним базовим потенціалом. Серед них високу цінність становить сорт Авантюрин [5].

Головною метою наших досліджень було створення скоростиглих і високоврожайних сортів сої для всіх зон України з високою технологічністю, тривалістю періоду вегетації 80-95 днів, урожайністю насіння 3,0-4,0 т/га вмістом протеїну 40-43\%, вмістом жиру $22-26 \%$.

Методика проведення досліджень. Для створення сортів і впровадження їх у Полтавській, Харківській, Сумській, Дніпропетровській облас- 
тях використано джерела адаптивності до лімітуючих факторів (шляхом гібридизації) 3 метою оцінки на посухостійкість, стійкість проти хвороб, до кислих грунтів і комплексу кліматичних чинників. Закладання польових і лабораторно-польових дослідів і фенологічні спостереження проводили відповідно до Державних стандартів України та методичних вказівок державного сортовипробування. Характеристику морфо-біологічних ознак протягом вегетації проводили згідно 3 уніфікованим класифікатором роду Glycine [6].

Результати досліджень. Надаємо коротку морфо-біологічну характеристику сорту Авантюрин. Сорт з 2015 року занесено до Державного реєстру сортів рослин, придатних для поширення в Україні.

Морфологія. Тип росту - проміжний. Рослина має напівстиснутий кущ, висотою 71-90 см. Стебло середньої товщини - 7,0-12,0 мм, стійке до вилягання. Забарвлення опушення - руде. Кількість міжвузлів - 10-15 штук. Кількість гілок - 1-3, кут



Рис. 1. Загальний вигляд рослини сорту

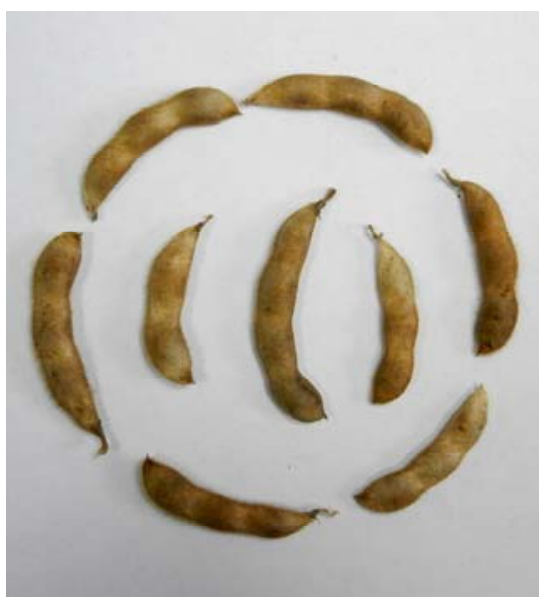

Рис. 3. Боби з рослини сорту Авантюриі їх відгалуження - 20-30 ․ Висота кріплення нижнього бобу - 12-15 см. Коренева система добре розвинена. Листки трійчасті, середніх розмірів. Суцвіття - багатоквіткова китиця, по 5-7 квіток. Забарвлення віночка квітки - фіолетове. Боби середньої довжини, слабко зігнуті, з гострим кінчиком, з 2-3 насінинами, світлі, 3 рідким опушенням. Насіння - середнє $(0,6 \times 0,4$ см), округлоовальне. Основне забарвлення оболонки - жовте. Також іноді має коричневу пігментацію різної інтенсивності. Інтенсивність пігментації насіннєвої оболонки може змінюватися залежно від умов вирощування. Маса 1000 насінин - 180-200 г. Вміст білка в насінні - 38 \%, жиру - $22 \%$ (рис. 1, 2, 3, 4).

Сорт зернового напряму використання. Стійкість проти вилягання і розтріскування бобів за тривалого перестою - висока. Насіння швидко втрачає вологу під час достигання. Сорт стійкий проти бактеріальних і вірусних хвороб, шкідниками пошкоджується слабо.

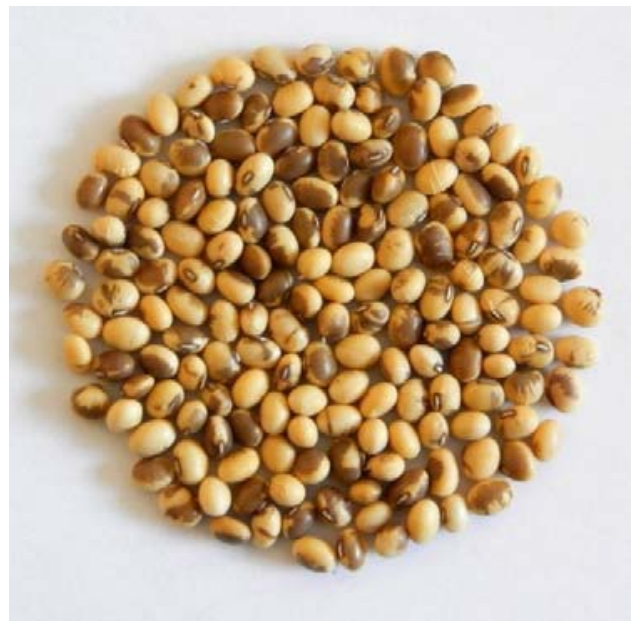

Рис. 2. Насіння сорту Авантюрин

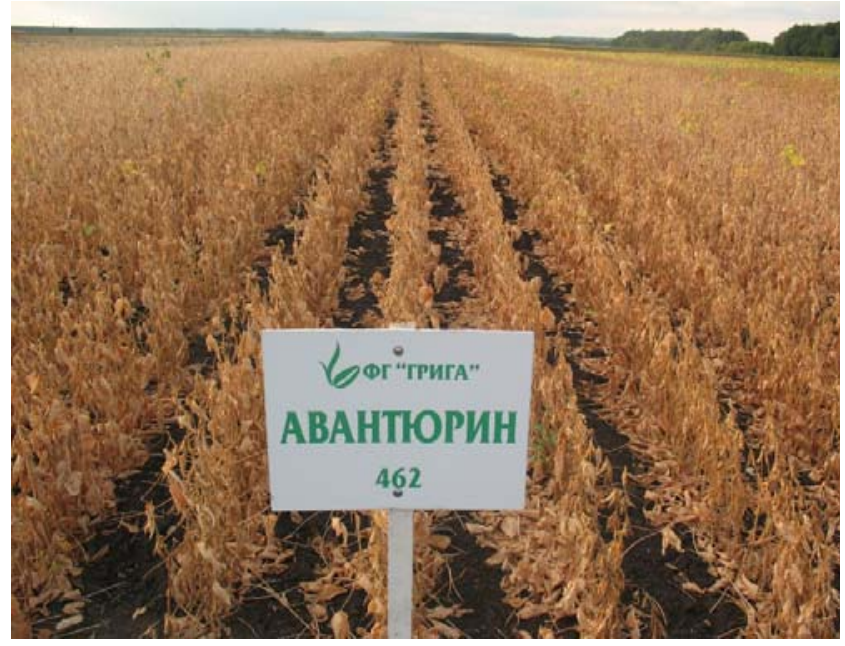

Рис. 4. Загальний вигляд посіву сорту 


\section{СІЛЬСЬКЕ ГОСПОДАРСТВО. РОСЛИННИЦТВО}

Агротехніка сорту Авантюрин - загальноприйнята. Норма висіву - 550-650 тис. штук схожих насінин на гектар. Сорт добре реагує на внесення добрив і передпосівну інокуляцію насіння біопрепаратами.

Сорт рекомендований для вирощування на зерно у Степу і Лісостепу України. Вирівняність насіння - $95 \%$. В умовах господарства ТОВ «ХОРОЛ-АГРО» (Полтавська область, Хорольський район) у виробничих посівах формує 3,03,5 т/га насіння.

\section{БІБЛІОГРАФІЯ}

1. Бабич А. О. Кормові і білкові ресурси світу. - К. : Аграрна наука, 1996. - 822 с.

2. Білявська Л. Г., Пилипенко О. В., Діянова $A$. O. Особливості насінництва сортів сої селекції ПДАА // Конкурентноспроможне насіння - стабільний урожай : тези міжнар. наук.-практ. конф. (30-31 січня 2013 р.). - Полтава : ПДАА. - 2013. - C. 55-56.

3. Braun H. I., Rayaram S., Van Ginkel M. U. Cimmyts approdach to breeding for wide adaptation // Euphitica, 1996. - 92. - №1-2. - P. 175-183.

4. Білявська Л. Г., Пилипенко О. В., Діянова А. О.
Висновок. Вдало підібраний господарством сорт значною мірою компенсує негативний вплив на очікуваний урожай грунтовокліматичних умов вирощування, використання недосконалої техніки, дефіцит мінеральних добрив і засобів захисту рослин тощо. Сорт сої Авантюрин рекомендований для вирощування у всіх зонах України, скоростиглий та високоврожайний, має значний потенціал і високу стабільність врожаю по роках.

Високоадаптивні сорти сої Полтавської селекції // Посібник Українського хлібороба. Мін. АПК. Інститут рослинництва ім. Юр'єва. - 2013. - Т. 2. - C. 150-151.

5. Державний реєстр сортів рослин, придатних для поширення в Україні в 2016 році. Режим доступу

http://vet.gov.ua/sites/default/files/Reestr\%2006042 016.pdf.

6. Широкий уніфікований классифікатор рода Glycine max (L.) Merr. - Харків : Магда LTD, 2004. $-37 \mathrm{c}$.

\section{ANNOTATION}

Biliavska L. G., Vasetskyi Yu. P., Biliavskyi Yu. V., Diianova A. O. Early ripening soybean variety Avantiuryn.

Soybean, its uses, genetic potential, customer and processer requirements are considered in the study. Growth of soybean demand has been stated. Ways of increasing soybean output in Ukraine in accordance with climatic zones of Ukraine are defined. Thereafter, ways and perspectives of formation of soybean variety resources in the country are considered. A great number of various soybean varieties, most of which with narrow environmental and geographical adaptation have been recorded into the State Register of plant varieties adaptable to distribution in Ukraine. According to the modern requirements soybean variety has to be high-yield, adaptive, possess high genetic potential and appropriate degree of resistance to biotic and abiotic environmental factors as well. The part of early ripening high-yielding soybean varieties has been growing. This crop is an excellent preceding crop for winter wheat.

Nowadays the variety is a mean of yield growth as well as a factor of increasing economic efficiency of production.

The main research objective was to select early ripening and high-yield soybean varieties for all

zones of Ukraine with high processability degree, the duration of vegetation period of 80-95 days, seed yield of 3.0-4.0 t/ha, protein content of 40 $43 \%$ and fat content of $22-26 \%$ as well.

In order to select and introduce the varieties in Poltava, Kharkiv, Sumy and Dnipropetrovs'k regions sources of adaptability to limiting factors (by hybridization) have been used with the aim to estimate drought-resistance, disease resistance, resistance to acid soil and complex of climatic factors as well. Field and laboratory-field experiments, phenological observations have been carried out in accordance with the State Standards of Ukraine and methodical recommendations of the state variety trial. Morphological and biological characteristics during the vegetation period have been described according to the unified classifier of the kind Glycine.

Early ripening variety with increased basic potential has been selected by the method of hybridization of adaptability sources to stress environmental factors on the basis of many years' practical experience in the soybean selection field. Avantiuryn variety has been recorded into the State Register of plant varieties adaptable to distribution in Ukraine.

Some requirements to the agrotechnics elements have been given. 
Plant height is 71-90 centimeters. Height of attachment of bottom bean is $12-15 \mathrm{~cm}$. Weight of 1000 seeds is $180-200$ grams. Protein content of seed is $38 \%$, fat content is $22 \%$. Potential grain yield in the conditions of Ukraine is 3.0-3.5 t/ha. The variety is characterized by increased adaptability to unfavourable growing conditions including growing on acid soil ( $\mathrm{pH} 4.5-5.5)$.

The variety grown for grain production is resistant to lodging and bean splitting. The variety is resistant to bacterial and virus diseases and slightly damaged by pests. Agrotechnics of Avantiuryn variety is standard. Seeding rate is $550-650$ thousand germinable seeds per one hectare. The variety is well responsive to fertilization and presowing seed inoculation with biological preparations. This variety is recommended to be grown for grain production in Steppe and Forest-Steppe of Ukraine. Size equality of seed is $95 \%$.

Key words: soybean, variety, selection, early maturation, variety description, economic characteristics, yield. 